\title{
95. New Discovery of Colpospira (Acutospira), Gastropoda, from Taiwan and Philippine
}

\author{
By Saburo Kanno,*) Wataru Hashimoto, C. C. Lin, Naoaki Aoki,**) \\ C. S. LeE, ${ }^{* * *)}$ N. L. CaAgusan, ${ }^{\dagger)}$ H. C. LiU, ${ }^{\dagger+}$ C. C. WANG, ${ }^{\dagger+}$ \\ K. S. ShIEH, ${ }^{\dagger \dagger}$ and H. C. ChANG ${ }^{\dagger \dagger)}$
}

(Communicated by Teiichi Kobayashi, M. J. A., Oct. 14, 1985)

Turritellid gastropod of genus Colpospira Donald, 1900, has been reported from Australia, New Zealand, and Sulawesi (Celebes), ranging from Eocene to Recent in Australia and Eocene to Oligocene in New Zealand (Marwick, 1957), and Eocene in Sulawesi (Beets, 1950) and Japan (Kotaka, 1959). T. Kotaka (1959) established a new subgenus Acutospira under the genus Colpospira which is characterized by having sharp edged whorls. He discriminates three species under the subgenus Acutospira among the Japanese turritellids mollusks; namely, Colpospira (Acutospira) okadai (Nagao), 1928, C. (A.) tashiroi Kotaka, 1959, and $C$. (A.) yabei Kotaka, 1959. All of them are restricted in the Eocene formations in northwestern Kyushu, Japan.

Excepting abovementioned species, there is no record on the occurrence of the genus in northern hemisphere of Indo-Pacific region up to date.

K. Tan (1936), W. Hashimoto et al. (1973), C. C. Lin (1974), S. Kanno, W. Hashimoto, C. S. Lee et al. (1976-77), and S. Kanno, W. Hashimoto, H. C. Liu, C. C. Wang, K. S. Shieh and H. C. Chang (1984) were engaged in the geological survey around the Kuanshan-Yakou area along the Southern Cross Highway of Taiwan. Especially, Kanno and Lee (1976-77), and Kanno et al. (1984) concentrated on their purpose for the collection of molluscan fossils from the Kuanshan-Yakou area and to make clear the stratigraphic relation of them.

Molluscan fossils distribute between the east side of Kuanshan-Yakou Tunnel and Hsuehfeng Bridge (Fig. 1), where thick irregular alternation of sandstone and slaty black shale or phyllitic slate is developed, though "graphite schist" (near the tunnel) and greenish tuffaceous "phyllite" (near the Hsuehfeng Bridge) are exposed in some places. Mollusean fossils occur from the alternation of rather coarse-grained sandstone $(15-50 \mathrm{~cm}$ in thickness) and slaty black shale $(20-40 \mathrm{~cm}$ in thickness), which shows almost NE-SW strike and $25^{\circ}-45^{\circ}$ southeast dips.

Among the fossil localities in Kuanshan-Yakou area, loc. 3 (Fig. 1) yields only turritellid mollusks which make a shell beds of about $5 \mathrm{~cm}$ in thickness, and loc. 5 in the same figure yields mostly deformed bivalves and turritellid shells which are concentrated respectively in several beds of coarse-grained sandstone and slate. However, a few individuals of turritellids and bivalves occur sporadically from the other localities.

\footnotetext{
*) Department of Geoscience, Joetsu University of Education.

**) Institute of Geoscience, the University of Tsukuba.

***) Energy and Mining Research and Service Organization, Taipei.

†) Philippine National Oil Corporation.

††) Central Geological Survey, Taipei.
} 


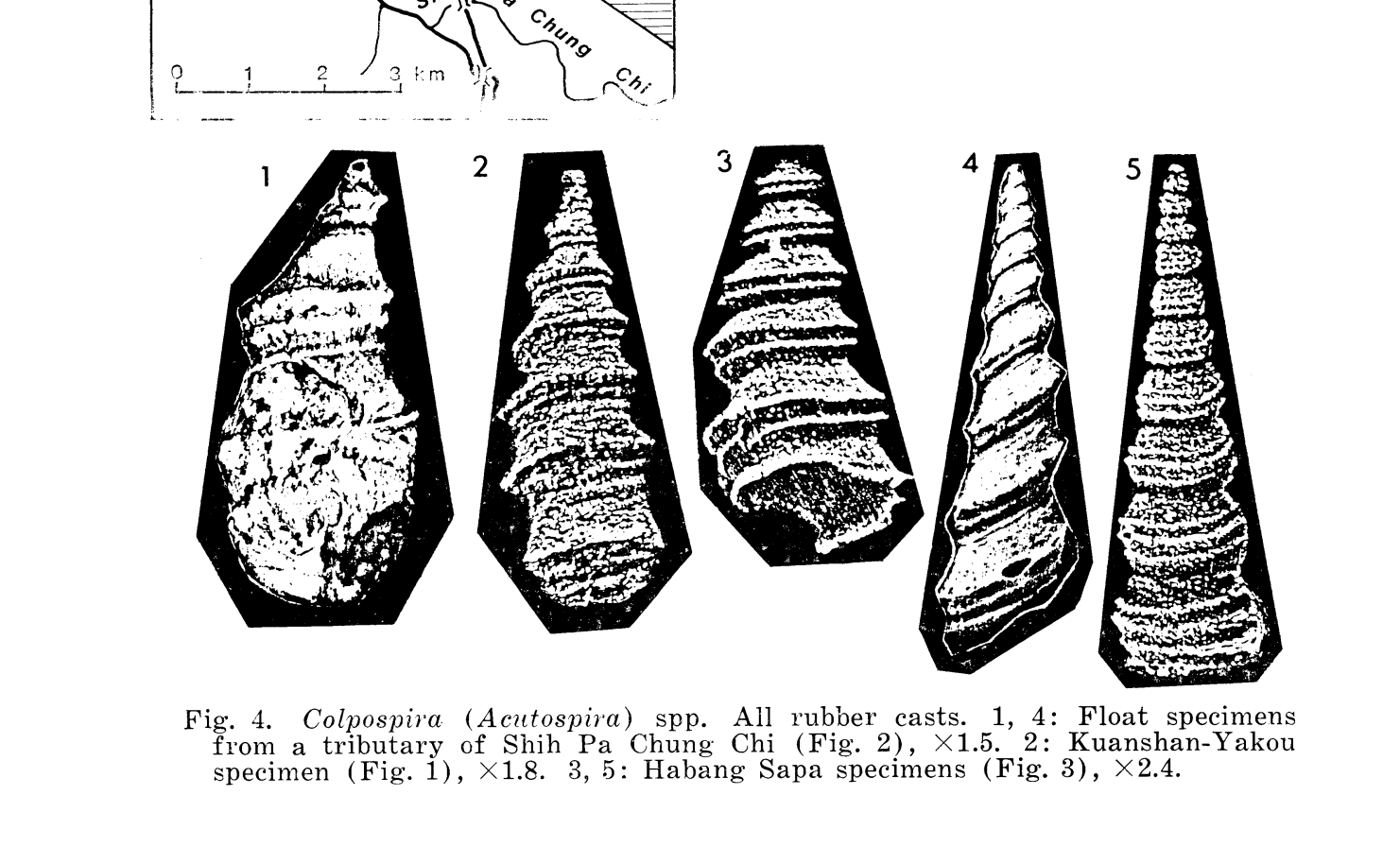


Turritellid specimens from the Kuanshan-Yakou area are characterized by having very acute spiral whorls which are somewhat similar to that of Colpospira (Acutospira) yabei Kotaka (1959, pp. 104-105, pl. 13, figs. 11-17), reported from Okinoshima Eocene in Nagasaki Prefecture, Kyushu, Japan. However, it is easily distinguished from the present one by having more blunt edged whorls, a fine spiral thread just above and below of the edge of whorl, while a fine spiral thread runs just below the acute edge of the respective whorl in the present specimens. Then, this specimen seems to represent a new species (Fig. 4).

The same specimens were collected as a float from two places near Suili, Nantou Prefecture, Central Taiwan (Fig. 2). S. Kanno, W. Hashimoto, C. S. Lee et al. (1976-77) collected turritellid shells from a huge boulder which consists of medium-grained brownish gray siliceous sandstone which lies on the river floor of Chun Keng Chi, about $4.8 \mathrm{~km}$ upstream from the junction of the Chen $\mathrm{Yu}$ Lan Chi and Chun Keng Chi (Fig. 2).

S. C. Lee (1979) reported the geology of Yushan-Suili area in Central Taiwan, and he found some turritellids-bearing floats from a tributary of Shih Pa Chung Chi (Fig. 2). These floats seem to be derived from the Paileng Formation (Eocene) which distributes around the small tributary. In August of 1984, writers visited this small valley and collected many turritellid-bearing floats at the valley, but could not find any exact exposure of its exact source rocks. However, the drainage area of the valley is not so broad, then, turritellid-bearing strata seem to be exposed within the drainage area of this small valley. These float specimens are also characterized by having very acute whorls just same as Kuanshan-Yakou specimens.

W. Hashimoto and T. Sato (1968) reported the geology of Mindoro, in which they pointed out that the Eocene formations are developed in the drainage area of Habang Sapa Creek and Taoga River, tributaries of Baroc River, near the town of Mansalay, Oriental Mindoro (Fig. 3). Therefrom they collected a float with turritellid which identified as Colpospira (Acutospira) sp. by Kanno. They recognized turritellid shell beds in several horizons in this area (Fig. 3).

In $1970, N$. L. Caagusan also collected turritellid specimens from the headwater of Habang Sapa Creek, a tributary of Baroc River, and it seems to be from the same locality as Hashimoto and Sato's one in 1968. The specimens collected by Caagusan include two species of Colpospira (Acutospira); namely, C. (A.) yabei and C. (A.) sp. from Taiwan by the writers (Fig. 4).

It is noteworthy that genus Colpospira distributes not only in Australia and New Zealand as well as Sulawesi of the Indo-Pacific region of the southern hemisphere, but it becomes clear that this genus distributes in Philippine and Taiwan as well as northwestern Kyushu of southwestern Japan in northern hemisphere in Eocene age. Accordingly, the genus Colpospira possibly invaded into northwestern Kyushu, Japan, from around Sulawesi vir Philippine and Taiwan in Eocene age. However, the exact geologic age of the Colpospirabearing strata of Sulawesi has to make clear before going to the conclusion of the trend of migration of the genus.

Acknowledgements. The authors are particularly indebted to Central Geological Survey, Energy and Mining Research and Service Organization in Taiwan, Chinese Petroleum Corporation, and Philippine National Oil Corporation for their kind assistance in the field works. The authors wish to express their thanks to the Ministry of Education, Japan, and the Japan Exchange Association for the financial support in their field work. 


\section{References}

Beets, C. (1950): On the lower Tertiary mollusca from S. W. and Central Celebes. Leidsche Geol. Mededeel., vol. 15, pp. 282-290, with 1 pl.

Donald, M. (1900): On Turritellidae and Murchisoniidae. Proc. Malac. Soc. London, $4(2)$, pp. 47-55.

Hashimoto, W., and Sato, T. (1968): Contribution to the geology of Mindoro and neighboring islands, the Philippines. Geol. Paleont. S.-E. Asia, vol. 5, art 65, pp. 192210 .

Kotaka, T. (1959): The Cenozoic Turritellidae of Japan. Sci. Rep. Tohoku Univ., ser. 2, $31(2), 1-135$, with 15 pls.

- (1982) : Geologic history of Japanese Turritellid fauna in Japan and adjacent regions. Bolletino della Societá Paleontologica Italiana, vol. 21, nos. 2-3, with 1 pl.

Lee, C. S. (1979) : Paleogene rocks of the Yushan-Suili area, Natou, Central Taiwan. Mem. Geol. Soc. China, no. 3, pp. 237-247.

Marwick, J. (1957) : Generic revision of the Turritellidae. Proc. Malac. Soc. London, 32, pt. 4, 144-166, with 70 text-figs.

Nagao, T. (1928): Paleogene fossils of the Islands of Kyushu, Japan. Part 1. Sci. Rep. Tohoku Imp. Univ., ser. 2, vol. 9, no. 3, pp. $97-128 \mathrm{~m}$ with 5 pls.

Tan, K. (1939) : New fossil locality of Eocene Foraminifera and the geologic age of diabasic greenish igunious rocks from the middle part of the Central range of Taiwan. Taiwan Tigaku Kizi (Bull. Geol. Taiwan), vol. 10, no. 1, pp. 1-16 (in Japanese). 